\title{
FABP1 wt Allele
}

National Cancer Institute

\section{Source}

National Cancer Institute. FABP1 wt Allele. NCI Thesaurus. Code C51240.

Human FABP1 wild-type allele is located within $2 \mathrm{p} 11$ and is approximately $5 \mathrm{~kb}$ in length.

This allele, which encodes fatty acid-binding protein, liver, is involved in fatty acid

metabolism in the liver and is important for bile acid regulation. The allele may also play a role in intracellular lipid transport. 